\title{
The ‘Australian’ COMMUNITY: Bound for more of the Same?
}

\author{
Transforming Cultures eJ ournal, \\ Vol. 2 No 1, November 2007 \\ http:// epress.lib.uts.edu.au/journals/TfC
}

\section{Fiona McAllan}

\begin{abstract}
In this paper I interrogate why a nation grounded with an overarching assumption of a unified community is increasingly being confronted with ruptures, breaches and anomalies when it comes to indigenous inclusion. I search the intersections of current political rhetoric and indigenous relations to uncover an entrenched colonialism in relation to this inclusion. Following Nancy's notion of partage, which connotes a sharing while sharing out, and the structure of 'engaging with' rather than 'deciding for', I sketch an originary relation of ethos that questions the material effects of a community homogenously bounded by ownership and entrepreneurialism ${ }^{1}$.
\end{abstract}

\section{Introduction}

Australian society is represented in the Howard government rhetoric as a harmonious unity, where all nationalities can live their quotidian moments within a tolerant diversity, with everyone pulling together for the national good. The guiding principle in this unity is that individuals cohere through a particular 'Australianness', enabling the premise of 'equality before the law' to apply across the board ${ }^{2}$. But what unified version of 'Australianness' could be constructed without compromising cultural difference, considering the historical trajectories of the 'settlers' in this country? What 'sameness' will not contradict this premise of equality before the law?

As 'Australians' are collectively encouraged by the government to embody selfdetermining entrepreneurialism in this nationally bounded solidarity, sites of pronounced inclusion/exclusion in 'Australian' communities increase. The nation's communities have historically been organised within homogenising forces in which

\footnotetext{
${ }^{1}$ I'd like to acknowledge John Lechte, Jane Durie and my anonymous referees for their helpful comments regarding the preparation of this paper.

${ }^{2}$ I use inverted commas to highlight the process of construction in these terms.
} 
each successive government's projection of a shared national vision of 'Australianness' retains its colonially derived foundation. The assumption of Crown ownership of this country initiated this process of possession that positions individuals as participants in the property-based economy that began at 'settlement'.

Aileen Moreton-Robinson argues that a "possessive logic works ideologically to naturalise the nation as a white possession”. The Crown's exclusive possession of territory that founds the nation state "is predicated on exclusion of what it does not own, indigenous sovereignty” (Moreton-Robinson 2004: 5). Epistemologically, through a patriarchal white possessiveness, "the intersection between race and property plays a definitive role in constructing and affirming indigenous dispossession” (ibid: 22). It is particularly clear that the notions of 'sameness' and 'equality' create very contradictory conditions regarding property relations for indigenous peoples.

The homogenously bounded nation, under the Howard government particularly, incorporates indigenous peoples as either 'non-white' possessing participants or as dispossessed. In other words, they are included as excluded (Agamben 2003), or included if they agree to give up their cultural specificity and conform to the homogenous community that participates in this nationally founded colonial vision. This applies to any others deemed threatening to this homogeneity, as all succeeding migrants conform to this 'property-owning' identity. Colonial dispossession is built into the very operations of racialised power that institutionally and legislatively defines the nation (Giannacopoulos 2007: 11).

In this paper, from my position as a non-indigenous researcher, I elaborate on how indigenous dispossession, or indigenous peoples' inclusion as exclusion, remains the groundwork of the homogenous national community in 'Australia'. Insistence on 'property-owning' identity relies on a binary opposition that operates between ongoing cultural erasure of indigenous peoples and constructions of legitimate 'settled' ownership and possession.

I first look closely at how indigenous relations of belonging reflect symbiotic coexistence and reciprocity between people and land, and how post structural ethics resonate with these relations by considering inter-subjectivity and negotiation. Then, in 
looking at the issues of Native Title legislation in the Yorta Yorta case, the Howard government's recent intervention in Northern Territory communities, changes to Land Rights legislation and the condemnation of customary law, I explore continuing relations that perpetuate subordination, erasure and alienation of indigenous relations of belonging.

I also reveal how indigenous peoples actively resist this unified community that denies the pre-existence and continuity of their laws and ways of being. Their resistance witnesses how the experience of community is in fact the sharing of our incommensurable differences. Our interrelated coexistence needs to be open to disagreement and fracture (Secomb 2000: 137) in order to refuse the possessive relations that disconnect us from each other and our lived world. I argue that community is what takes place in the interrelations between recognition and continued resistance to unified conformity.

\section{Belonging}

From the earliest settler contact, indigenous peoples have been denied their very different law and land relations, which recognise belonging 'to' rather than 'possessing' land. Irene Watson explains the myth of terra nullius as the colonisers perceiving this country as "available to be filled with their beginnings of history and evolving spirit" (Watson 2002 13). Indigenous law relations have been developed within systems of kinship responsibilities, structured through reciprocity with each other and the land. Colonial Australian law, organised within the overarching structure of ownership in the Crown, created a fixed relation with the land and capital, dispossessing the original occupants and relegating them to the outer fringes of the 'Australian' community. Indigenous pre-existing laws and ways of being in this country continue to threaten the legitimacy of this national community.

Ideological assumptions that require community members to perceive and behave in the same way deny the lived structure of community, in that every individual has an incommensurably different perspective. To decide for the other is to erase their difference. Self-determining equal subjects are only made possible by constructing an oppressed other. As Social Justice Commissioner Tom Calma has argued, the presumption of an identical needs-based (formal) equality before the law has long been 
recognised as insufficient to eliminate racial discrimination. The human rights committee adopts a substantive equality that takes into account individual concrete circumstances and is able to recognise specific aspects of discrimination (Calma 2001: $50)$.

Following Jean Luc Nancy, an unconditional community accepts that subjects are not fixed identities but are always reconstituting in relation to each other. Difference is the finitude or limit that each individual shares with the other. Contrary to a selfdeterminism, Nancy says there can be no 'I' but only 'we' because subjects constitute in relation with others. The only way to allow for an incommensurable subjective perspective is to mutually recognise this fundamental subject-to-subject relation. Nancy finds that in sharing this limit relation, finitude takes place as community. Being finite is "being-in-common". He sketches this relation as "partage”, which means both a partition and a partaking, or both a sharing and sharing out (Nancy 1990).

As all people are both joined and separated through their differences, this relation of partage can be seen as the ongoing structure of all relations. This continuous yet originary relation is a paradoxical relation that irreducibly separates while communicatively joining all relations. Communication is a "sovereign operation transgressing at the limit of discursive difference” (Derrida 1985: 115). This relation is an ethos, to follow Derrida, the manner of being (Derrida 2001: 13). Ethos, as a structural law, irrupts fixed structures created to organise sameness, where difference becomes appropriated.

Linnel Secomb has interpreted community as productive disagreement which disrupts the violence of assimilation based in unity. While she argues Nancy's vision of community as sharing overcomes reductive commonality, she finds that Nancy "gives insufficient attention to the forms and strategies of resistance against union and assimilation" and "turns away from sustained formulation of how difference is enacted and maintained” (Secomb 2000: 143). I would emphasise the aporetic relation between recognition and resistance and the doubled structure of subjectivity that exceeds this opposition as the place of community. Nancy's work on "being singular plural” (Nancy 2000) sketches iterating subjectivity as both finite/infinite, demonstrating the doubled relation of differing while deferring. While singularity cannot avoid differentiation 
constitutively, Derrida explains a-teleological deferral, where limit and difference are shared, is the place of affect:

self-engendering doubling is (also) a self-differing, that is, the now doubles itself in such a way as to become a not-now to be retained in another now ... the living now, producing itself by spontaneous generation, must, in order to be a now, be retained in another now ... Such a process is indeed a pure selfaffection in which the same is the same only in affecting itself from the other (Derrida in Sallis 1992: 133, 134).

Self-affection, beyond oppositions, is both recognising, and beyond finite recognition (Oliver 2000).

Secomb acknowledges the doubled relation between recognition and resistance when she points to indigenous peoples' coexistent yet irreducible relations in law and Country. Their political strategy regarding indigenous sovereignty:

simultaneously demands recognition and refuses recognition: demands acceptance and refuses assimilation... [it] involves both negotiation and reconciliation and, simultaneously, resistance and disagreement (Secomb 2000: 146).

Self, other, and Country are interconnected. Moreton-Robinson explains that, as white law assumes indigenous law is constituted through a normative system made up of a collective body of conforming people, it misses how traditional laws are:

intrinsic to an inter-substantiation of human ancestral beings and land. Indigenous people are the human manifestations of land carrying title to land through and on their bodies (Moreton-Robinson 2004: 12).

Watson argues:

all peoples come into the laws of place, as they come into ruwi (country), even krinkis (non-indigenous) but the greater majority has no sense or recognition of laws of place as they are controlled by the idea of sovereignties of state (Watson 2002: 17).

\section{Inter-subjective relatedness}

While fixed overarching and centralising structures continue to ideologically bind people within a colonially imagined organisation of self-sameness, a reconceptualising from the perspective of inter-subjective relatedness can reveal opportunities for mutual reciprocity and allow for negotiation in the ongoing shared production of meaning. Secomb, resonating with Derrida, finds community is an activity of interrelation, and the processional passage that unbinds is not absolute non-communication but the expression of difference. So while the following discussion still signals indigenous and 
non-indigenous subjective relations, I therefore hope that the processes of identity construction in inter-subjective relations can remain the focus, rather than reinscriptions of fixed identity constructs of 'indigeneity' and 'Australianness'.

As ongoing materia/cultural constructions, inter-subjective relations constitute in genealogical differentiations, always specifically located. The white colonialist may have presumed an 'Englishness', yet 'Englishness' was constructed constitutively through descendents from different lands, along with abstractions of ideological connotations and assumptions. Indigenous relations have also constitutively constructed in relation with people from other locations, especially since colonisation when the colonialist/indigenous opposition began. Again, 'whiteness', is not an 'English' production, but occurs as an invisible reification of privilege in racially operative modes of power. So while this discussion is not intended to signal a conglomerate amassing of genealogical convergence, rather, it aims to signal the specificity that is retained socioculturally and constitutively as inter-subjective relations continue in their singular/plural trajectories and historicity. As the relation of partage reveals, genealogical trajectories retain distinctiveness within new connections, and are open to ideological reification. And new connections always bring the past with them in ongoing presence.

\section{Law and land relations}

When the colonialists assumed a foundation for the framework of ownership in the Crown in what is now known as 'Australia', more than 250 indigenous language groups with over 500 dialects had lived, symbiotically engaged with their lands and each other, and their own law relations, for countless generations. Yet these laws have continued to structure indigenous relations within their lived experience in the present. Watson writes:

Our laws are lived as a way of life, not written down, as knowledge of law comes through the living of it. Law is lived, sung, danced, painted, eaten, walked upon, and loved, law lives in all things ... It has no inner or outer, for one is all, all is one. Law is what holds this world together (Watson 2006).

Indigenous relations remain people- and land-centric (Watson 2005). So while the legacy of colonisation has been the reliance on objective control of Crown land, strategically managed through the accumulation of property and capital, from an intersubjective perspective there is no objective separation from land and each other. Indigenous cultural relations, when unhindered by colonial systems, demonstrate a 
mutual recognition of this intricate relationship of land and people and collective responsibility for the reciprocal relations between. Language group boundaries and differences largely remain respected and are culturally elaborated by corresponding language groups as they share mutual responsibilities along connective boundaries and sustained kinship relations (Bird Rose 2006; Simpson 2004).

'Country' is not an abstract concept in indigenous culture but a living entity, lived in and lived with. The notion of 'Country' is where all elements are engaged communicatively, because there is no position from which the interest of one can be disengaged from the interests of others in the generality. What is integral to understanding this interdependence of living systems is that concepts of selfdetermining individuality and ownership are problematic, as they are a source of competitiveness and alienation, disconnecting from inter-relational engagement and reciprocity (Bell 1998 25) . $^{3}$.

The difference between custodianship and ownership is pronounced. Rather than possessively controlling land, having access to, and responsibility for, land is integral to relations of custodianship. Responsibility to Country is a relation that is fundamental to the ongoing cycles of finitude and renewal, to be shared by all peoples who partake of Country's resources. When deprived of access to ancestral lands and the ability to continue responsibilities and cultural connectivity, indigenous peoples are burdened with pronounced inequity in an 'Australian' community that establishes through abstractedly reified possessive relations. Yet despite massive material disruption, many continue to practise, as far as possible, these reciprocal kinship relations, even in heavily urbanised locations ${ }^{4}$. The construct of a level playing field of self-sameness produces a place of contradiction for indigenous peoples. In the requirement to embody and articulate the entrepreneurial culture through ownership and self-determining accumulation, indigenous relations of kinship and communally negotiated law and land relations are threateningly different and so become marked as 'other' to the supposed homogeneity of 'Australian’ community.

\footnotetext{
${ }^{3}$ See also Goodall (1996), McGrath (1995), Butlin (1993).

${ }^{4}$ Reconciliation groups engagement with indigenous communities has revealed the extent of sustained elder leadership and ongoing cultural connectivity with urban communities. See Aboriginal Support Group Network in Manly/Pittwater, for example, at <http://www.asgmwp.net or www.antar.org.au >
} 


\section{Indigenous land relations - Yorta Yorta}

In parcelling up the land and violently assimilating the threat of indigenous difference, indigenous laws of mutual reciprocity with land and each other were overridden and disregarded for the colonial laws of Crown tenure, significantly disrupting language, kinship structures and cultural relations of belonging. Indigenous peoples who survived the initial violence were relegated to the fringes of early settlements and then within protectorates and missionaries, and subjected to the policies of the Aboriginal Protection Board. The Stolen Generation was a further attempt to assimilate the cultural differences of indigenous peoples as children were removed from their families to be institutionalised or 'raised' by 'settler' families ${ }^{5}$. Moreton-Robinson argues that ‘Australian' law has been crucial to systemic discrimination where constructions of Aboriginality are always directly linked to policies of control of indigenous people (Moreton-Robinson 2006).

Despite the acknowledgment in Mabo that indigenous peoples did have their own laws at the time of 'settlement', which overturned of the assumption of terra nullius as the foundation for Crown law, Native Title cases demonstrate a continuing extinguishment of indigenous rights and interests in land (Watson 2002: 30). Despite the acknowledgement that this foundation has been imposed over pre-existing and continuing indigenous laws, the laws of tenure in the British Crown remain in place through 'Australia's' common law, assuming the authority to either recognise or dismiss native title. The justices argued that the overarching and fixed skeletal frame of Crown tenure should not be fractured (Mabo v Qld: 43).

While the 'Australian' High Court decided that the question of what constitutes the sovereignty of the 'Australian' state was non-justiciable (Watson 2002: 30), it nevertheless assumed the authority to extinguish indigenous interests if it determines they have lost their cultural continuity through dispossession. If the court decides the 'tide of history' has simply washed away evidence of traditional laws and customs, this metaphor continues to operate to legislatively presume indigenous peoples no longer have connection with their land (Wik v Qld 1996: 231). In the Mabo case it was decided that Native Title was not a creature of common law, yet common law had the power to

\footnotetext{
${ }^{5}$ Between 1910 and 1970 up to 100,000 indigenous children were forcibly taken from their families by police or welfare officers. See <http://www.enair.org/issues/stolengenerations.html >
} 
recognise it. In the Yorta Yorta case it was further decided that oral accounts of traditional laws and customs were unreliable and therefore common law could not give effect to them.

Moreton-Robinson argues that the Howard government's amendments to the Native Title Act since Mabo increase and protect property rights and further erode indigenous rights (Moreton-Robinson 2006: 129). She finds the possessive logic of whiteness precludes indigenous people from representing ownership, so that claimants are presented as holders of ancient tradition rather than property owners (ibid: 125). "Terra Nullius [continues to be] reproduced through positioning [the Yorta Yorta] as a landless people” (ibid: 133). The justices required evidence of physical presence "based on conceptions of white property ownership that requires evidence of human occupation in the form of fences, title deeds or residences, as the signifiers of white possession” (Moreton-Robinson 2004: 15-18). This becomes opposed to presumably fragile and imprecise oral accounts, in order to protect the "intergenerational transfers of inherited wealth that pass on the spoils of discrimination to succeeding generations" (Lipsitz in Moreton-Robinson 2006: 130).

Indigenous claimants in the Yorta Yorta case were subjected to a gruelling and demeaning enquiry to prove that they are still practising the same traditions, in the same way, in the same place, as at contact in 1788. Many elders of the community gave intimate accounts of their genealogical trajectories and the significance of their ongoing cultural practices, which had incorporated modifications from the co-impaction of settler/indigenous relations since contact. Despite this, the extinguishment of the Yorta Yorta's rights and interests in their lands was decided by the credence given to a property-hungry squatter's observations (Curr) of the Yorta Yorta at contact, rather than the contemporised expertise via the oral histories of the present custodians (Yorta Yorta v Vic 1998: 106).

Through the reification of white property continuity and white interpretations of what constitutes tradition, the Yorta Yorta's survival, through adapting while resisting white culture, was used as proof that they had surrendered their indigeneity and their sovereignty (Torres \& Milus in Moreton-Robinson 2004: 23). In removing indigenous peoples from their lands and subordinating them with gross inequity, there is a deep 
contradiction in the requirement to prove a museum-like connection with traditional practices prior to 1788 . The Yorta Yorta were thus denied their right to historical change, and "refused the continuity of indigenous sovereignty as the precondition and genesis of all concomitant rights, interests, entitlements, responsibilities, obligations, customs and law” (ibid: 24).

It is possession that is recognised and protected by common law, and not traditional laws and customs that "allocate rights, interests and responsibilities within communal possession and regulate their exercise by community members” (Torres \& Milus in Moreton-Robinson 2004: 20). Moreton-Robinson reminds us that indigenous sovereignty invokes different sets of relations and belonging grounded in a different epistemology to patriarchal white sovereignty (2004: 12, 24). The knowledge that relations between indigenous peoples and their country are synonymous and symbiotic remains unrecognised, and as Watson has argued, krinkis also miss the recognition of their own "coming into laws of place". She writes:

Nungas co-existed in the law ... our identity is set in law and land... The colonial state cannot grant us who we are, for it was not theirs to give. Who we are emanates from law... Nunga relationships to ruwi [Country] are more complex than owning and controlling a piece of property... We nurture ruwi as we do our self, for we are one (Watson 2002: 18,19).

\section{Leasing indigenous land}

Native title cases have created further and more comprehensive processes of exclusion of indigenous-specific land relations for many indigenous communities. Contradictorily, the more communities have been impacted by colonial dispossession, the greater the pressure to prove the authenticity of their cultural continuity through 'settler' interpretation. For communities whose title has been recognised, (where property investments have not extinguished them), different operations of racialised power are now being utilised to dispossess and erase indigenous law and cultural difference. Through a possessively paternalist rhetoric, which gets taken up and conveyed by corporate-owned media with vested interests, the Federal Government has strategically sought to manage representations of Northern Territory indigenous communities as lacking in self-determination and property entrepreneurialism due to a generalised unmanageability and depravity in communities. Against these representations this government has constructed a guise of paternal legitimacy for its emergency intervention. 
On June 21, 2007, the Howard government declared 'a state of emergency' in the Northern Territory indigenous communities after the release of a report into child sexual abuse. Many previous reports over the 11 years of John Howard's terms as 'Prime Minister' had gone unheeded. Despite the Little Children are Sacred report being carefully prepared over 12 months, in respectful consultation with the communities, and 97 recommendations being made for systemic and effective change, the government ignored both the recommendations and any consultation with communities. Ongoing community consultation had been the first and most crucial recommendation in the report. Instead, under the instigation of military-trained Indigenous Affairs Minister, Mal Brough, troops were rushed in to the community of Mutitjulu, the first step in the 'taking control' of these communities. The 'Prime Minister' claimed to feel an outrage and urgency due to the 'squalid' conditions for children in these communities, compelling him to intervene without notice (Howard 2007).

Within a month the federal government rushed in new legislation in relation to this intervention, giving the senate less than a day to consider the new legislation's 500+ pages. The bills make changes to the Land Rights Act, by abolishing the permit system that has recognised indigenous access laws to Country, as well as taking leases over at least 70 communities, assuming control of their land for a 'proposed' five-year term. The legislation included an unconstitutional clause that ensured compensation monies 'on just terms' could be sidestepped, effectively enabling the repossession of indigenous titled land (Brown 2007). Legal specialists decried how the legislation contravened the Racial Discrimination Act, as the bills simply included clauses to bypass the Act (National Indigenous Times 2007: 1).

There were also directives for the Territory government to resume control of Alice Springs town camps if it was decided their sub-leasing conditions had been breached (Koorie Mail 2007: 1). In May 2007 the Alice Springs town camps had rejected for a second time the offer of $\$ 60$ million to sublease their land for 99 years to the government (National Indigenous Times 2007: 2). Over the previous two years there had been increasing pressure to conform to the government's entrepreneurial and individualist agenda regarding property, and increasingly appropriative measures were operating to erase the threatening difference in indigenous kinship land relations. The connection between the resumption of titled land and child abuse was questioned by 
health professionals, legal experts, the indigenous communities, politicians and even the police (Koorie Mail 2007: 2).

The first moves to amend the Land Rights Act 1976, regarding 99 year leases, had become apparent in February 2005 when, buttressed with the argument of economic self-determination, the then 'Minister for Indigenous Affairs' Amanda Vanstone had announced: "We are going to cut through the present slow, cumbersome and costly processes that people have to go through to get a lease on Aboriginal land" (Vanstone 2005:1). The government had proposed the leasing of entire towns on indigenous land, to be negotiated by the government, the Lands Council and traditional owners, with the professed aim of increasing indigenous home ownership. The minister appeared completely ignorant of how contradictory the requirement was for indigenous peoples to conform to the mode of entrepreneurial individualism in property.

When this was announced Central Land Council Director David Ross explained that the average income of indigenous peoples in the Northern Territory was $\$ 9,000$, so that not many were in a position to buy a house even if heavily discounted (Ross 2005:1). Ross had earlier pointed to the historically low level of investment in indigenous communities by all governments. An example he gave was the fact that for every dollar spent on education of non-indigenous children in Darwin, a child in the indigenous community of Wadeye had been allocated only 26 cents (Ross 2005: 2). But the contextual detail of the ongoing inequity in relations for indigenous peoples was not the focus of the government's possessive logic.

Senator Vanstone provided an indication of what was at the centre of the government's concerns in indigenous land relations, considering the ideological pressure to conform to economic development in relations of property. She stated: "There's a huge portion of land ownership and there doesn't seem to be anywhere enough wealth being generated” (Vanstone 2005: 2). As traditional custodial laws engage communal rights, the resumption of custodial relations between people and their traditional lands, where living off the land is practised, is a continuing difficulty for property relations and the narrative of economic development. This difference in land relations continues to irrupt the ideological mechanisms of self-same property relations. 
Michael Dodson, then Director of Reconciliation, said at the time: "Howard's trying to get rid of communal ownership, his religious and spiritual traditions don't allow for this form of communal ownership” (Dodson 2004). NSW Democrats Senator Ridgeway concurred that the Prime Minister's approach to indigenous relations is "drawn from a Western perspective that prizes individualism" and illustrates a "profound cross-cultural misunderstanding” (Ridgeway 2005). In the ongoing debate centred on economic productivity and self-determinism, the cultural significance of indigenous communality continues to be targeted ideologically as the cause of economic dysfunction. As Dodson was expressing the sociality of indigenous kinship relations, mainstream press reported: "the argument that traditional cultural values are essential to Aboriginal wellbeing is not good enough any more” (The Weekend Australian Sept 26, 2005).

What is especially contradictory in the 99-year lease ammendments is that individualism is articulated through the legislative recognition of whole corporations as singular bodies, which, in each case, works against indigenous communal resourcing. Ross argued:

it will enable the Northern Territory government to lease entire communities and subsequently sub-lease to whoever it chooses ... Aboriginal people are being forced to pay for these new arrangements from the Aboriginal Benefits Account [which consists of royalties paid as compensation for mining of indigenous land] which is to pay for community development purposes (Ross 2005: 3).

It is clear that it is indigenous relations with the land that threatens possessive tenure relations. The media-controlled rhetoric that represents indigenous communal ownership as in need of paternal management removes context and does not publicise continuing measures to destabilise communally-run communities. The 99-year lease ammendments were rushed through Parliament in August 2006 against the express wishes of Northern Territory indigenous communites and despite many senators deploring the lack of consultation. Greens Senator Siewert stated to parliament:

Government has not consulted on this issue ... I must question the government's motives to rush this legislation through. The ultimate aim of this legislation may be to diminish the power of land councils, destabilise government structures, increase the power of the minister and take away control from traditional owners so that outsiders can come in and exploit their land and resources (Siewert 2006).

The senator was also concerned about the taking of control from traditional owners for four generations, and questioned how the leases could be said to be voluntary when 
communities were already having vital services, at crisis levels of depravation, withheld if they didn’t sign up. The Territory's Labor Senator Crossin, in a passionate speech questioning the rushed bill, argued:

this is not about self-determination, this is about saying to indigenous people... 'You have to behave like whitefellas in this country... own your own home'... this government just doesn't get it... indigenous peoples... have an intrinsic relation with the land (Crossin 2006).

The media-supported rhetoric of self-determination reveals the exercise of possessive patriarchal whiteness as it continues to deny the fundamental structure of community. Interrelations in people and Country express the continuity of differing and deferring, they contain the meaningful expressions of affective existence itself. Watson argues it is necessary for different realities to be put in place, in which different ways of knowing can dismantle the unequal powers of Western systems (Watson 2002: 7). This possessiveness is what she calls muldarbi and she describes it as a sickness "divided and separated from itself”. It is yet to know the freedom that comes from living/singing law (ibid: 18, 48).

Indigenous expressions of self-determination do not resemble the government's representations of self-determinism in any way. As indigenous relations recognise the finite and infinite responsibilities to land and each other, there can be no disconnection from this interrelatedness in Country. Self-determinism can only depend on mutually recognised responsibilities that are engaged in community, both individually and collectively. It is both a recognition of finite relations and the infinite relations beyond our recognition. And this highlights the necessity of protecting the specificity of individual circumstances in our relatedness.

\section{Customary law relations}

The leasing legislation was not the only indication that Federal Government strategies were afoot much earlier than the June 2007 intervention. In June 2006 indigenous customary law in the Territory had suddenly become represented as the cause of widespread violence in indigenous communities. The call for heavy police control and the focus on customary law by Indigenous Affairs Minister Brough was apparently in response to alleged paedophile rings and tribal violence. Brough called for the overturning of the amendments to legislation that had ensured cultural consideration in indigenous criminal sentencing, claiming "we should have the same approach right 
across the board ... We're all Australians. We should apply the same set of laws and the same values” (Brough 2006).

The inquiry into Aboriginal Deaths in Custody in 1999 had led to the Council for Aboriginal Reconciliation's recommendation to recognise the role and importance of customary law in indigenous communities. It was clear that this recognition would effectively reduce the number of indigenous offenders entering prison, enabling them to avoid the violence they suffered there. As the majority of indigenous crimes were for minor offenses, and mandatory sentencing in the Territory did not allow for differentiation between terms of imprisonment and seriousness of crime, it was clear that mandatory sentencing was a deeply discriminatory law (Calma 2001: 33-5).

Customary law courts bring offenders before their community and elders, where their individual circumstances are considered in the context of their responsibilities to community. Such courts were set up in most states, showing immediate success. The attorney general in Victoria described the state's nine Koorie courts as the jewel in the justice system, as recidivism rates had reduced to almost half of non-indigenous offenders (Hulls 2006). Yet in the Territory, where less urbanisation had meant less hindrance to traditional lifestyles, the government had only gone as far as introducing mandatory minimum periods of detention. After much criticism of mandatory sentencing, legislation was amended to enable diversionary schemes for juveniles and an interpreting service. One such scheme had been set up in the community of Mutitjulu.

By July the National Indigenous Times had painstakingly exposed the details in circumstances that had led to the media conflation of customary law and paedophilia, preceding Brough's determination to abolish cultural considerations (NIT 2006: 1). In the community of Mutitjulu, where the rape of a juvenile girl had occurred, the offender had been ostracised by his community, as customary law required, seven months before the media stories were aired. This particular incident had become caught up in what became a vehicle of misrepresentation through the media focus on the condemnation of customary law. The incident highlighted ongoing systemic disaffection from years of exclusionary policies and chronic destabilisation of cultural systems in communities like Mutitjulu. Yet, while this incident was a direct violation of customary law, it was 
manipulated in the media to appear to be an enactment of customary law privilege and therefore indigenous customary law, at base, was represented as the cause for widespread violence.

An elaborate story covered by ABC's Lateline featured paedophile rings, drug monies and sex slavery, and an interview with an anonymous youth worker from Mutitjulu. The NIT revealed that this particular youth worker was actually a senior official within OIPC (Office of Indigenous Policy Coordination) who, while in touch with the Minister, had provided a sensational and fictitious account (see also Crossin 2006: 2). The NIT revealed that the alleged drug money, which was supposedly connected with widespread paedophile rings, had nothing to do with indigenous communities at all but rather a particular white criminal in Darwin. The claim of paedophile rings was never substantiated and Brough later withdrew the statement about drug monies. Brough was later publically called to account by members of the Mutitjulu community for his misrepresentation of customary law, and a lengthy complaint was lodged with the ABC (NIT 2006: 2).

Customary law had been caught up in an ideological construction that covered over protracted unequal underspending on infrastructure in remote communities and perpetuated misrecognition of indigenous cultural difference in the perception of the ‘Australian’ community. As Lester-Irabinna Rigney pointed out in an insightful and nuanced article at the time, it is not the violence in indigenous culture, but the violence to indigenous culture that causes the problems. He states "The attack on customary law by Mr Brough can be considered as further entrenching violence to Aboriginal culture” (Rigney 2005). Instead of allowing for inter-relational connections to be made and for recognition of inter-subjective relatedness, indigenous cultural difference was marked out as the threat in the 'settled' 'Australian' community. Government funding to the Mutitjulu community was withdrawn at this point with accusations of mismanagement and an external administrator was assigned to take over their affairs. At the time of the intervention the community had since been without a doctor, and their limited health services had been reduced ${ }^{6}$.

\footnotetext{
${ }^{6}$ Correspondence with Mutitjulu community members.
} 
In the attempt to interrupt this ideological representation of customary law as violence, the then Shadow Minister for Indigenous Affairs, Senator Evans, pointed to the efficacy of customary law in indigenous communities. He argued that if respected and negotiated with appropriately, customary law increases efficiency in cross-cultural legal relations. He argued that the bluster over customary law was designed to distract attention from the government's poor track record in addressing family violence, stating "while the current debate suggests that violence and abuse are products of indigenous cultures, in fact...the reverse is true". He argued the systematic erosion of traditional cultural practice perpetuates these problems:

the proposition that those who argue for the maintenance of indigenous cultures are condoning violence ... is not only offensive but undermines efforts to understand ... Measures to combat violence which are based in false assumptions about indigenous culture and formed without indigenous input are ineffective at best and actively damaging at worst (Evans 2006).

ANU law professor Jennifer Clarke also revealed the distortions in the government's ideological representation of indigenous culture, and refocused on underlying contributors to crime which she argued were connected with social inequity and disrupted social infrastructure (Clarke 2006). The inaccuracy of conflating customary law with paedophilia had outraged the Mutitjulu community, as it distorted perceptions of indigenous cultural practice. Clarke also noted the government's inability to comprehend how customary law would continue in indigenous relations despite legislative moves to abolish it. Though the reification of 'Australian' culture reduces non-indigenous engagement in indigenous culture, it does not render it null. For a culture that has at least 120,000 years of archeologically recorded history ${ }^{7}$, customary law reflects a reciprocity fundamental to indigenous cultural practices. What both Clark's and Evans' arguments demonstrate is the need to engage with the contextual detail of particular circumstances, and the structural necessity to allow for, and negotiate with, difference in law relations to avoid the violence of appropriation.

The Koorie Justice Centres operating in Victoria and Community Justice Centres operating in other states ${ }^{8}$ have enabled criminal relations to be dealt with as face-to-face negotiations before the elders and community. Incidents are handled as a community

\footnotetext{
${ }^{7}$ Information provided to me by an Indigenous Cultural Officer at Metro. Land Council Sydney.

${ }^{8}$ See Koorie Justice May 2005 edition 6, a Victorian Government booklet The Victorian Aboriginal Justice Agreement in Action and <http://ntru.aiatsis.gov.au/ifamp/practice/practice_contents.html >
} 
experience where offenders have access to the full impact of their crime, opportunity for recompense for the victim and the chance for the resumption of reciprocal relations. Customary laws are laws of place, always situated, grounded in the circumstantial relations between community and Country. They can be seen to engage the ethos of inter-subjective responsibility. This does not occur in an objectifying overarching structure that disconnects from laws of place and the specificity of context to presume the equality of self-sameness - a presumption that determines 'we' are all 'Australians' with the 'same' law and the 'same' values.

It is clear to see this 'same' law at work when looking at the connections and interrelations underlying the emergency intervention in the Territory that has resulted in the takeover of indigenous communities' land. It is the appropriative power of possessive whiteness that calls for the application of this 'law of the same' to be applied to indigenous offenders, while taking away of any consideration of their cultural difference. And it is this possessiveness at work in the 'law and order' regime now set up in the Territory, under the guise of eradicating sexual abuse. As the legislation was rushing through the senate, there had been no charges laid in relation to the supposedly rampant abuse, despite the roll out of troops, police and medical teams.

A week before the intervention the Mutitjulu community won a protracted legal battle that proved the government's claim of mismanagement had been incorrect and the external manager was dismissed (ABC 2007). Yet the regime ignored the concerns of indigenous communities, health professionals, human rights and social justice advocates, lawyers, politicians, and academics across the country, who were questioning the dubious connection between taking land and ensuring wellbeing and also the taskforce’s ability to see connections between social determinacy and health. Clearly, this 'one' law of muldarbi, while omitting the specific context, continues in its sick, disconnected possessiveness, to reproduce indigenous peoples as the included excluded, in order to ground and legitimise the sovereign sameness of the 'Australian' community. Watson exhorts:

our laws go before and beyond a sovereignty which is held by a physical force of arms. Aboriginal law is exterior to a claimed sovereignty of the muldarbi, an exteriority that renders their claimed sovereignty a breach and violation of our natural order as their rules and regulations maintain the unlawfulness of tyranny (Watson 2002:40). 


\section{Reciprocal relations}

This paper has looked at relations of inequality that are perpetuated and reinforced for indigenous peoples in the fixed structure of 'Australianness' overarching the 'Australian' community. It has also explored contradictions that come up in the pressure to conform to the ideological constructs of homogeneity and sameness in community, particularly considering the possessive entrepreneurial individualism reinforced by the Howard Federal Government. What has been offered as a way forward in transformative relations is that the focus should be reformulated to consider the finite/infinite structure that inter-subjective relations share, recognising this as the lived structure of community in Country. This is a focus that would provide opportunity for inter-subjective cultural exchange to be mutually responsive in its engagement. To maintain a colonialised control in indigenous communities is to keep the mechanisms hidden that compromise interrelational responsiveness.

Indigenous cultures have largely been relegated ideologically to a "cultureless remnant" (Birch 2005:151) and indigeneity objectively assessed as perpetually inadequate in taking on the reified entrepreneurial cultural apparatus. Bounded representations of sameness, modelled on colonially derived constructs of 'Australianness', misrepresent the cultural experience of inter-subjectively lived relations in this country. This is a paternalistic denial of the socio-cultural interchange that has been lived since the colonial encounter. Relations of indigenous belonging are compromised by the denial of their sovereignty and cultural difference and the continued possessive logic of tenure in land that does not comprehend that all people come into laws of place. All relations are compromised by a fixed ideological structure that requires omission of specificity in context and a conformity that requires disengagement from individual difference. This structure does not properly address the constitutive relations of finitude and renewal and partitioning and partaking that are multiply shared. And it will not properly address the richness of cultural difference that constitutes in mutual responsivity and reciprocal relations in communities.

\section{Bibliography}

Australian Broadcasting Commission (2007) "Mutitjulu wins fight against administrator's appointment”, online report, Friday June 15, 2007. Retrieved June 19, 2007 at <http://www.abc.net.au/news/stories/2007/06/15/1952853.htm> 
Agamben, G (2003) Homer Sacer Vol 2, Torino: Bolati Boringhieri.

Bell, HR (1998) Men’s Business Women’s Business. Vermont: Inner Traditions.

Birch, Tony (2005) in Michele Grossman (ed) Blacklines, Melbourne: Melb Uni Press.

Brough, M, Minister for Indigenous Affairs (2006) The 7.30 Report. Broadcast 23 May, 2006. Sydney: ABC Television. Retrieved July 10 at: <http://www.abc.net.au/7.30/content/2006/s1645722.htm>

Brown, B, Evans, C, Siewert R (Senators) (2007) Senate committee to question the Northern Teritory intervention bills. Federal Parliament channel Digital 44, televised August 14, 2007.

Butlin, N (1993) Economics and the Dreamtime. Cambridge: UP.

Calma, T (2001) Social Justice Report. Chapter 3 at 50, and chapter 4 at 33-35. Retrieved August 10, 2007 at:

$<$ http://www.humanrights.gov.au/social_justice/ customary_law/nt_lawreform.html>

Clarke, J. ““Abolishing' 'customary law' will do little to reduce violent Aboriginal crime.” Canberra Times, July 3, 2006. Retrieved July 12, 2006 at:

$<$ http://law.anu.edu.au/cipl/Expert\%20Opinion/

06'Customary\%20law'\%20and\%20crime\%20-\%20J\%20Clarke.pdf >

Crossin, Senator T. Consideration of Legislation Speech. Retrieved June 28, 2007 at: $<$ http://www.trishcrossin.com.au/html/speech_2006_08_09a.html>

Derrida, J (2001) Negotiations - Interventions and Interviews 1971-2001. California: Stanford University Press.

Derrida, J (1985) "Writing and Difference”, pp 251-77 in F. Botting, \& S. Wilson eds (1998). Bataille: A Critical Reader. UK/US: Blackwell Publishers.

Dodson, M (2004) The World Today. ABC Radio, December 6, 2004.

Evans, Senator C. “Brough’s myths must be dispelled”, Labor eHerald, June 19, 2006. Retrieved June 19, 2006 at:

<http://eherald.alp.org.au/articles/0606/natp20-01.php >

Giannacopoulos, M (2007) "Nomos Basileus: The Reign of Law in a World of Violence”, in ACRAWSA ejournal, Vol. 3, No.1.

Goodall, H (1996) Invasion to Embassy, Land in Aboriginal Politics in NSW, 17701972. Sydney: Allen \& Unwin.

Howard, J. ABC Online Reports. Retrieved June 21, 2007 at:

$<$ http://www.abc.net.au/message/news/stories/ms_news_1958792.htm

Hulls, R, Attorney General (2007) Living Black. SBS Television, series 6, episode 11. Retrieved August 10, 2007 at:

http://news.sbs.com.au/livingblack/index.php?action=proginfo\&id=373

Koorie Mail (2007: 1). Wednesday July 4, p 9.

Koorie Mail (2007: 2). Wednesday July 18, pp 8-10.

Lateline ABC evening broadcasts, June 21\& 23, 2006. ABC Radio PM program, June 21.

McGrath, A (1995) Contested Ground: Australian Aborigines under the British Crown. Sydney: Allen \& Unwin. 
Moreton-Robinson, A (2004) "The Possessive Logic of Patriarchal White Sovereignty: The High Court and the Yorta Yorta Decision”, Borderlands ejournal, Vol. 3, No. 2.

Moreton-Robinson, A (2006) "Terra Nullius and the Possessive Logic of Patriarchal Whiteness: Race and Law Matters.” pp.123-135 in Changing Law: Rights, Regulation and Reconciliation. Ed. Hunter, R \& Keyes, M. Ashgate, Hants.

Nancy JL (1990) The Inoperable Community. Paris.

Nancy, JL (2000) Being Singular Plural. Great Britain: Stanford University Press.

National Indigenous Times (2007: 1) Thursday August 9, 2007, p 20.

National Indigenous Times (2007: 2) Thursday July 12, 2007, p 6.

National Indigenous Times (2006: 1) Thursday July 27, 2006, p 4-10.

National Indigenous Times (2006: 2) Thursday November 2, 2006, p3.

Ridgeway, A (2005) Addressing the Economic Exclusion of Indigenous Australians through Native Title. Mabo Lecture, National Native Title Conference, June 3, 2005. Retrieved April 10 at:

<http://www.aitsis.gov.au/rsrch/ntru/conf2005/papers/papers.html>

Rigney, Lester-Irabinna (2006) Aboriginal Cultural Violence or Violence of Aboriginal Culture. Retrieved August 10, 2006 at:

$<$ http://www.antar.org.au/index.php?option=com_content\&task=view\&id $=251 \&$ temid $=106>$

Rose, DB, Meehan B (2006) Nourishing Terrains. Retrieved August 4, 2006 at $<$ http://www.abc.gov.au/publications/generalpubs/nourishing/intro>

Ross, D (2005: 1) Radio National, ABC. 5 October, 2005.

Ross, D (2005: 2) Central Land Council Media Release. April 5, 2005.

Ross, D (2005: 3) Central Land Council Media Release. Retrieved October 5, 2005 at <http://www.clc.org.au/media/releases/2005/land_rights_act_changes.asp>

Sallis, J (1992) “Doublings”, in Wood D (ed), From Derrida, A Critical Reader. UK: Blackwell.

Secomb, L (2000) “Fractured Community”, Hypatia Vol. 15, No. 2.

Siewert, Senator R (2006) Parliamentary speeches, August 8, 2006. Retrieved October 7, 2006 at

<http://www.rachelsiewert.org.au/500_parliament_sub.php?deptItemID=58>

Simpson, Leanne. (2004) "Anticolonial Strategies for the Recovery and Maintenance of Indigenous Knowledge”, American Indian Quarterly, 28(3\&4): 373-384.

The Australian (2005) Editorial, “Putting people first”, September 26, 2005. Retrieved October 24, 2007 at:

<http://www.koorieweb.org/foley/news/austed26sep05.html>

Vanstone, A, Minister for Indigenous Affairs (2005: 1) Media release. Retrieved October 5, 2005 at <http://www.atsia.gov.au/media/media05/v0535.htm>

Vanstone, A, Minister for Indigenous Affairs (2005: 2) Address to the National Press Club. Retrieved April 10, 2007 at <http://www.atsia.gov.au/media/speeches/23_02_2005_pressclub.htm> 
Watson, I (2002) “Aboriginal Law and the Sovereignty of Terra Nullius”, Borderlands ejournal. Retrieved September 20, 2006 at $<$ http://www.borderlandsejournal.adelaide.edu.au/ vol1no2_2002/watson_laws.html>

Watson, I (2005) “Some Reflections on Teaching Law”, Indigenous Law Bulletin, DecJan, 2005, Vol.6 Issue 8.

Wik Peoples $v$ the State of Queensland (1996) 141 ALR 129 at 231.

Yorta Yorta $v$ State of Victoria \& Ors (1998) 1606 FCA. 